\title{
Pengaruh Penggunaan Media Berbasis Information Technology Pada Pembelajaran IPA Terhadap Prestasi Belajar Ditinjau Dari Kemandirian Belajar
}

\author{
Endang Lestari ${ }^{7}$, Sunardi ${ }^{8}$, Nunuk Suryani ${ }^{9}$ \\ yunaiuns@yahoo.com
}

\begin{abstract}
The purpose to be achieved in this research is to know; 1) differences in the influence of the use of media ICT and conventional learning against learning achievement in grade $V$ Diponegoro Cluster Elementary Schools, 2) the difference between the effect of learning independence in the high and low categories of the learning achievement of students in grade $\checkmark$ Diponegoro Cluster Elementary Schools, 3) the interaction of the use of ICT media and learning independence on the learning achievement of the students of grade $V$ Diponegoro Cluster Elementary School. This type of research uses the 2x2 Factorial Experimental Method. The research population was all elementary school students of grade V Diponegoro Cluster Elementary School, Bae sub-district, Kudus. The research is using Random Sampling Clusters, Selected SDN 2 Dersalam and SDN 1 Dersalam. Data collection techniques is using questionnaire and test. Hypothesis testing is using Two Path ANAVA Technique. The results of the study are: 1) there is significant differences in the influence of ICT learning media and conventional learning on science learning achievement (Fcount 4,808> Ftable 4,000), 2) there is significant differences in the effect of learning independence on science learning achievement (Fcount 4,770> Ftable 4,000), and 3 ) there is a significant influence of learning media interaction and learning independence on science learning achievement (Fcount 4.402> Ftable 4,000).
\end{abstract}

Keywords: ICT Media, Learning Independence and Science Learning Achievement

\footnotetext{
${ }^{7}$ Mahasiswa Magister Teknologi Pendidikan Universitas Sebelas Maret

8 Dosen Magister Teknologi Pendidikan Universitas Sebelas Maret

${ }^{9}$ Dosen Magister Teknologi Pendidikan Universitas Sebelas Maret
} 


\section{PENDAHULUAN}

K egiatan belajar mengajar IPA di Gugus Diponegoro UPT Pendidikan Kecamatan Bae Kudus pada umumnya masih kurang mandiri, hal ini dikarenakan peserta didik kurang aktif dalam proses kegiatan belajar mengajar di kelas dan cenderung pasif. Hal ini dikarenakan peserta didik masih bergantung pada guru dan peranan guru di kelas masih dominan. Berdasarkan nilai Ujian Akhir Semester (UAS) semester ganjil tahun ajaran 2014/2015 menerangkan masih ada 25\% dari jumlah peserta didik yang belum tuntas dan nilai rata-rata kelas 72,5 . Menurut Kurikulum Tingkat Satuan Pendidikan bahwa batas ideal ketuntasan adalah 75. Jika KKM SD disesuaikan KTSP maka yang tidak lulus KKM ada 57\% dan rata-ratanyapun tidak mencapai KKM ideal. Kondisi tersebut tidak boleh dibiarkan berlarut-larut dan guru dituntut menjadi profesional yang harus dapat mengembangkan diri dan mengikuti perkembangan jaman. Berdasarkan fenomena yang ada di Gugus Diponegoro UPT Pendidikan Kecamatan Bae Kudus maka pemilihan metode, media, dan pendekatan dalam pembelajaran di kelas perlu dilakukan dalam upaya meningkatan kemandirian belajar peserta didik.

Rendahnya hasil belajar peserta didik ini disebabkan antara lain pendekatan dalam pembelajaran yang masih didominasi oleh guru yang menempatkan peserta didik sebagai objek, sehingga peserta didik banyak bergantung pada gurunya dalam proses belajar. Masalah itu terjadi terus-menerus dalam proses pembelajaran di sekolah yang menyebabkan peserta didik tidak mandiri karena selalu bergantung dengan guru, oleh karena itu diperlukan upaya pembaharuan. Pembaharuan itu meliputi pembaharuan kurikulum, metode pembelajaran, kegiatan belajar mengajar, penilaian, media pembelajaran. Mengingat hal tersebut, dirasa perlu bagi seorang guru untuk mempunyai pedoman dalam pembelajaran di kelas yang meliputi strategi-strategi mengajar sampai metode, pendekatan maupun media yang dapat digunakan dalam pembelajaran. Teknik-teknik mengajar seperti itu tergantung pada kemampuan guru dalam mengembangkannya, terlebih lagi saat ini banyak media yang dipilh oleh seorang guru sebagai alat bantu pembelajaran dikelas sehingga proses pembelajaran dapat berjalan efektif dan efisien.

Kehadiran Teknologi Informasi ( $\mathrm{TI})$ dewasa ini mulai mempengaruhi penyelenggaraan pendidikan, berbagai model pengembangan pembelajaran berbasis $\mathrm{TI}$ ini seakan-akan tengah menjadi idola dan booming. Pengajaran dengan menggunakan media berbasis teknologi informasi (TI) atau dalam bahasa Inggris Information Technology (IT) belum banyak diterapkan, apalagi dalam mata pelajaran IPA. Beberapa sekolah yang dijumpai telah menggunakan aplikasi-aplikasi komputer sebagai alat bantu mengajar, tetapi juga ada beberapa sekolah yang belum manfaatkan alat bantu tersebut. Beberapa guru beralasan diataranya: mengalami kesulitan dalam mengoperasikan, kesulitan dalam membuatnya, membutuh waktu lama untuk mempersiapkan, ada juga yang beralasan karena keterbatasan sarana dan prasarana (Wijaya, 2012).

Berdasarkan hasil observasi, Gugus Diponegoro UPT Pendidikan Kecamatan Bae Kudus sudah memiliki peralatan komputer dan proyektor sebagai media pembelajaran tetapi jumlahnya sangat terbatas. Beberapa guru tidak mengetahui cara menggunakan komputer dan cenderung enggan menggunakannya. Zaman sekarang dimana teknologi berkembang sangat pesat menjadikan komputer sangat penting baik dalam pembelajaran maupun di luar pembelajaran. Sedangkan mata pelajaran $\mathrm{TI}$ belum dimasukkan ke dalam kurikulum sekolah, padahal mata pelajaran TI merupakan salah satu pelajaran yang mengajarkan teknologi yang berkembang saat ini. Sementara pada pembelajaran IImu Pengetahuan Alam, masih dijumpai pembelajaran yang hanya menggunakan metode ceramah dan peserta didiknya hanya mendengarkan sehingga terkesan pembelajaran menjadi kurang interaktif dan komunikatif. Kondisi seperti itu menjadikan peserta didik menjadi mudah bosan, jenuh, dan peserta didik kurang tertarik. 
UNESCO mengklasifikasikan tahap penggunaan TIK dalam pembelajaran ke dalam empat tahap sebagai berikut: 1) Tahap emerging, baru menyadari akan pentingnya TIK untuk pembelajaran dan belum berupaya untuk menerapkannya, 2) Tahap applying, satu langkah lebih maju dimana TIK telah dijadikan sebagai obyek untuk dipelajari (mata pelajaran), 3) Tahap integrating, TIK telah diintegrasikan ke dalam kurikulum (pembelajaran), 4) Tahap transforming merupakan tahap yang paling ideal dimana TIK telah menjadi katalis bagi perubahan/evolusi pendidikan. TIK diaplikasikan secara penuh baik untuk proses pembelajaran (instructional purpose) maupun untuk administrasi (administrational purpose) (Yuliatmojo, 2006). Fryer (2001) mengatakan bahwa penggunaan TIK dalam pembelajaran bertujuan untuk melatih keterampilan menggunakan TIK dengan cara mengintegrasikannya ke dalam aktifitas pembelajaran, bukan mengajarkan TIK tersebut sebagai mata pelajaran yang terpisah. Jadi, sudah saatnya TIK diintegrasikan ke dalam proses pembelajaran dan bukan hanya sekedar menjadi mata pelajaran yang terpisah. UNESCO (2002) menyatakan bahwa pengintegrasian TIK ke dalam proses pembelajaran memiliki tiga tujuan utama: 1) Untuk membangun "knowledge-based society habits" seperti kemampuan memecahkan masalah (problem solving), kemampuan berkomunikasi, kemampuan mencari, mengolah/mengelola informasi, mengubahnya menjadi pengetahuan baru dan mengkomunikasikannya kepada orang lain; 2) Untuk mengembangkan keterampilan menggunakan TIK (ICT literacy); dan 3) Untuk meningkatkan efektifitas dan efisiensi proses pembelajaran.

Dari sisi pendekatan, Fryer (2001) menyarankan dua pendekatan yang dapat dilakukan pendidik ketika merencanakan pembelajaran yang mengintegrasikan TIK, yaitu: 1) pendekatan topik (themecentered approach); dan 2) pendekatan software (software-centered approach). Selain pemanfataan media pembelajaran, untuk meningkatkan prestasi belajar peserta didik dituntut memiliki kemandirian belajar. Menurut Stephen Brookfield (dalam Budiarini, 2011) mengemukakan bahwa kemandirian belajar merupakan kesadaran diri, digerakkan oleh diri sendiri, kemampuan belajar untuk mencapai tujuannya. Menurut Sardiman dikutip oleh Achmad (2008) menyebutkan bahwa ciri-ciri kemandirian belajar yaitu meliputi: 1)Adanya kecenderungan untuk berpendapat, berperilaku dan bertindak atas kehendaknya sendiri 2) Memiliki keinginan yang kuat untuk mencapai tujuan, 3) Membuat perencanaan dan berusaha dengan ulet dan tekun untuk mewujudkan harapan, 4) Mampu untuk berfikir dan bertindak secara kreatif, penuh inisiatif dan tidak sekedar meniru. 5) Memiliki kecenderungan untuk mencapai kemajuan, yaitu untuk meningkatkan prestasi belajar, 6) Mampu menemukan sendiri tentang sesuatu yang harus dilakukan tanpa mengharapkan bimbingan dan tanpa pengarahan orang lain. Menurut Syam (1999), ada dua faktor yang mempengaruhi, kemandirian belajar yaitu sebagai berikut: Pertama, faktor internal dengan indikator tumbuhnya kemandirian belajar yang terpancar dalam fenomena antara lain: 1) Sikap bertanggung jawab untuk melaksanakan apa yang dipercayakan dan ditugaskan, 2) Kesadaran hak dan kewajiban peserta didik disiplin moral yaitu budi pekerti yang menjadi tingkah laku, 3) Kedewasaan diri mulai konsep diri, motivasi sampai berkembangnya pikiran, karsa, cipta dan karya (secara berangsur), 4) Kesadaran mengembangkan kesehatan dan kekuatan jasmani, rohani dengan makanan yang sehat, kebersihan dan olahraga. 5) Disiplin diri dengan mematuhi tata tertib yang berlaku, sadar hak dan kewajiban, keselamatan lalu lintas, menghormati orang lain, dan melaksanakan kewajiban. Kedua, faktor eksternal sebagai pendorong kedewasaan dan kemandirian belajar meliputi: potensi jasmani rohani yaitu tubuh yang sehat dan kuat, lingkungan hidup, dan sumber daya alam, sosial ekonomi, keamanan dan ketertiban yang mandiri, kondisi dan suasana keharmonisan dalam dinamika positif atau negatif sebagai peluang dan tantangan meliputi tatanan budaya dan sebagainya secara komulatif.

Berdasarkan latar belakang tersebut di atas, maka masalah dalam penelitian ini dapat dirumuskan: 1) Apakah ada pengaruh penggunaan media berbasis IT pada pembelajaran IPA terhadap prestasi belajar di Gugus Diponegoro UPT Pendidikan Kecamatan Bae Kudus? 2) Apakah ada pengaruh kemandirian belajar terhadap prestasi belajar di Gugus Diponegoro UPT Pendidikan Kecamatan Bae Kudus? 3) Apakah ada interaksi antara penggunaan media berbasis IT pada pembelajaran IPA dan kemandirian belajar terhadap prestasi belajar di Gugus Diponegoro UPT Pendidikan Kecamatan Bae 
Kudus? Adapun tujuan penelitian yang ingin dicapai: 1) Untuk mengetahui apakah ada pengaruh penggunaan media berbasis IT pada pembelajaran IPA terhadap prestasi belajar di Gugus Diponegoro UPT Pendidikan Kecamatan Bae Kudus. 2) Untuk mengetahui manakah yang lebih baik prestasi belajar peserta didik dengan kemandirian belajar tinggi atau kemandirian belajar rendah di Gugus Diponegoro UPT Pendidikan Kecamatan Bae Kudus. 3) Untuk mengetahui interaksi penggunaan media berbasis IT pada pembelajaran IPA dan kemandirian belajar terhadap prestasi belajar di Gugus Diponegoro UPT Pendidikan Kecamatan Bae Kudus.

\section{METODE PENELITIAN}

Penelitian dilaksanakan di Kelas V pada dua SD Negeri di Gugus Diponegoro Kecamatan Bae Kudus, pada pembelajaran semester genap tahun pelajaran 2014/2015. Penelitian ini dilaksanakan 5 bulan, mulai bulan Februari 2015 sampai dengan Juni 2015. Jenis penelitian ini adalah eksperimen menggunakan desain faktorial $2 \times 2$. Metode eksperimen adalah metode penelitian yang digunakan untuk mencari pengaruh perlakuan tertentu terhadap yang lain dalam kondisi yang terkendalikan (Sugiyono 2011). Populasi dalam penelitian ini adalah semua siswa Kelas V di SD Negeri Gugus Diponegoro UPT Pendidikan kecamatan Dawe Kudus. Teknik pengambilan sampel pada penelitian ini adalah Cluster Random Sampling Dari 2 kelas yang terpilih secara random dipilih kelas eksperimen dan kelas kontrol secara random. (SD 2 Dersalam/ SD 1 Dersalam).

Dalam penelitian ini ada 3 variabel, yaitu: 1) Variabel bebas (A) yaitu metode pembelajaran. 2) Variabel moderator (B) adalah kemandirian belajar siswa. 3) Variabel terikat adalah prestasi belajar IPA.

Metode pengumpulan data dilakukan dengan cara, yaitu: 1) tes kognitif mata pelajaran IPA 2) penyebaran angket untuk pengumpulan data kemandirian belajar peserta didik.

Sebelum instrumen digunakan sebagai penjaring data, maka diujicobakan terlebih dahulu. Uji instrument ini meliputi: 1) Uji Validitas Angket kemandirian belajar Peserta didik dengan Product Moment Pearson. 2) Uji Reliabilitas Angket kemandirin Belajar Peserta didik dengan rumus Kuder Richardson (KR-20). 3) Uji validitas tes prestasi belajar IPA menggunakan rumus Product Moment, 4) Uji reliabilitas tes prestasi belajar dengan formula KR-20, 5) Uji daya beda tes prestasi belajar, 6) Uji tingkat kesukaran tes prestasi belajar. Adapun teknik analisis data menggunakan uji analisis variansi dua jalan (ANAVA).

\section{HASIL PENELITIAN DAN PEMBAHASAN}

\section{Deskripsi Data}

\section{Deskripsi Data Kemandirian Belajar}

Jumlah responden $(N)=60$, skor terendah $=66$, skor tertinggi $=115$, mean $=86,43$ median $=$ 86,50, modus $=79$ standar deviasi $=9,28$, standar error of mean $(\mathrm{SE})=1,19$, kwartil $1(\mathrm{Q} 1)=80,25$ yang artinya $75 \%$ dari responden memiliki skor $>80,25$ kwartil $3(Q 3)=92,00$ yang artinya $25 \%$ dari responden memiliki skor $>92,00$.

\section{Deskripsi Data Prestasi Belajar IPA}

Jumlah responden $(N)=60$, skor terendah $=53$, skor tertinggi $=100$, mean $=77,60$ median $=$ 76,00, modus $=82$ standar deviasi $=12,51$, standar error of mean $(\mathrm{SE})=1,62, \mathrm{kwartil} 1(\mathrm{Q} 1)=65$ yang artinya $75 \%$ dari responden memiliki skor > 65 kwartil $3(\mathrm{Q} 3)=88$ yang artinya $25 \%$ dari responden memiliki skor $>88$.

\section{Deskripsi Data Prestasi Belajar IPA dengan Pembelajaran Berbasis IT bagi Peserta didik yang Mempunyai Kemandirian Belajar Rendah}


Jumlah responden $(N)=14$, skor terendah $=59$, skor tertinggi $=100$, mean $=77,29$ median $=76$, modus $=71$ standar deviasi $=11,30$, standar error of mean $(\mathrm{SE})=3,02$, kwartil $1(\mathrm{Q} 1)=69,5$ yang artinya $75 \%$ dari responden memiliki skor $>69,5$ kwartil $3(Q 3)=88$ yang artinya $25 \%$ dari responden memiliki skor $>88$.

Deskripsi Data Prestasi Belajar IPA dengan Pembelajaran Berbasis IT bagi Peserta didik yang Mempunyai Kemandirian Belajar Tinggi

Jumlah responden $(N)=16$, skor terendah $=59$, skor tertinggi $=100$, mean $=80,81$ median $=82$ modus $=59$ standar deviasi $=15,60$, standar error of mean $(\mathrm{SE})=3,90$, kwartil $1(\mathrm{Q} 1)=5,00$ yang artinya $75 \%$ dari responden memiliki skor $>65,00$, kwartil 3 (Q3) $=97,00$ yang artinya $25 \%$ dari responden memiliki skor $>94,00$.

Deskripsi Data Prestasi Belajar IPA dengan Pembelajaran Konvensional bagi Peserta didik yang Mempunyai Kemandirian Belajar Rendah

Jumlah responden $(N)=16$, skor terendah $=53$, skor tertinggi $=100$, mean $=75$ median $=73,50$, modus $=71$ standar deviasi $=11,07$, standar error of mean $(\mathrm{SE})=2,77$, kwartil $1(\mathrm{Q} 1)=66,5$ yang artinya $75 \%$ dari responden memiliki skor $>66,5$, kwartil $3(\mathrm{Q} 3)=82$ yang artinya $25 \%$ dari responden memiliki skor $>82$.

Deskripsi Data Prestasi Belajar IPA dengan Pembelajaran Konvensional bagi Peserta didik yang Mempunyai Kemandirian Belajar Tinggi

Jumlah responden $(N)=14$, skor terendah $=59$, skor tertinggi $=94$, mean $=77,21$, median $=82$, modus $=82$, standar deviasi $=11,76$, standar error of mean $(\mathrm{SE})=3,14$, kwartil $1(\mathrm{Q} 1)=65,00$ yang artinya $75 \%$ dari responden memiliki skor $>65,00$, kwartil $3(\mathrm{Q} 3)=83,50$ yang artinya $25 \%$ dari responden memiliki skor $>83,50$.

\section{Pengujian Persyaratan Analisis}

Pengujian Normalitas

Data kemandirian belajar diperoleh nilai signifikansi $p=0.721 \quad(p>0,05)$ yang berarti data kemandirian belajar berdistribusi normal, data prestasi belajar IPA menunjukkan nilai $p=0,345$ ( $p>0,05)$, maka dapat dikatakan bahwa data prestasi belajar IPA pada peserta didik yang diajarkan melalui media konvensional maupun menggunakan media berbasis IT berdistribusi normal.

\section{Pengujian Homogenitas}

Data prestasi belajar IPA menunjukkan nilai signifikasni $p=0,180(p>0,05)$, maka dapat dikatakan bahwa data prestasi belajar IPA pada peserta didik yang diajarkan melalui media konvensional maupun menggunakan media berbasis IT homogen. Artinya data variabel prestasi belajar IPA berdasarkan kemandirian belajar mempunyai varian yang sama.

\section{Pengujian Hipotesis}

Analisis statistik dengan bantuan program computer SPSS dengan menggunakan teknik analisis varians (ANAVA) dua jalur dengan desain factorial $2 \times 2$. Hasil Uji Anava dapat diinterpretasikan sebagai berikut

\section{Pengaruh Pembelajaran Menggunakan Media Berbasis IT dan Konvensioanl Terhadap Prestasi Belajar IPA}

Berdasarkan hasil perhitungan diperoleh $F_{\text {hitung }}=4,808$ dengan nilai signifikasi $p=0,037(P<0,05)$, hasil $F$ hitung $(4,806)$ lebih besar dari $F$ tabel $(4,00)$. Dari hasil perhitungan tersebut maka hipotesis yang menyatakan ada pengaruh penggunaan media pembelajaran berbasis IT terhadap prestasi belajar IPA 
terbukti kebenaranya. Artinya bahwa penggunaan media pembelajaran berbasis IT pada pembelajaran IPA terhadap prestasi belajar peserta didik memiliki perbedaan yang signifikan.

\section{Pengaruh Kemandirian Belajar Terhadap Prestasi Belajar IPA}

Berdasarkan hasil ANAVA perhitungan diperoleh nilai signifikansi $p=0,038(p<0,05)$ dengan nilai $F$ hitung $(4,770)$ lebih dari Ftabel $(4,00)$. Dari hasil perhitungan tersebut maka hipotesis yang menyatakan ada pengaruh kemandirian belajar terhadap prestasi belajar IPA di gugus Diponegoro UPT Pendidikan Kecamatan Bae Kudus, terbukti kebenarannya. Dari kedua tingkat kemandirian menunjukkan peserta didik yang memiliki kemandirian tinggi memiliki prestasi belajar yang lebih baik dibandingkan pada peserta didik yang memiliki kemandirian belajar kategori rendah.

\section{Interaksi Penggunaan Media Pembelajaran Berbasis IT dan Kemandirian Belajar Terhadap Prestasi Belajar IPA.}

Berdasarkan hasil perhitungan ANAVA diperoleh nilai signifikansi $p=0,024(p<0,05)$ dengan nilai $F_{\text {hitung }}=4,402$. Hasil perhitungan ini kemudian dikonsultasikan dengan tabel $F$ dengan Dkpembilang 1 dan Dkpenyebut $=59$ dengan taraf signifikansi 0,05 diperoleh $F_{\text {tabel }}=4,00$. Karena $F_{\text {hitung }}>F_{\text {tabel }}$ atau 4,402 > 4,000 , maka hipotesis yang menyatakan ada pengaruh interaksi penggunaan media pembelajaran berbasis IT dan kemandirian belajar peserta didik terhadap prestasi belajar IPA terbukti kebenaranya. Artinya ada interaksi pengaruh kemandirian belajar, pembelajaran menggunakan atau tidak menggunakan media pembelajaran berbasis IT dengan prestasi belajar IPA.

\section{PEMBAHASAN}

Pembahasan mengenai hasil penelitian yang dilakukan berdasarkan interpretasi data hasil tes belajar IPA sebagai berikut.

\section{Perbedaan pengaruh antara penggunaan media berbasis IT dan konvensional terhadap prestasi belajar IPA peserta didik Kelas V SD Negeri di Gugus Diponegoro Kecamatan Bae Kudus.}

Hasil pengujian dengan uji ANAVA diperoleh bahwa terdapat perbedaaan hasil belajar menggunakan media pembelajaran berbasis IT dengan pembelajaran konvensional, di mana nilai ratarata hasil belajar dengan media berbasis IT lebih besar dibandinglan dengan pembelajaran konvensional. Pada pengujian pengaruh, ditemukan bahwa penggunaan media pembelajaran IT berpengaruh positif dan signifikan terhadap hasil belajar IPA. Dengan demikian hipotesis yang menyatakan ada perbedaan pengaruh antara penggunaan media berbasis IT dan konvensional terhadap prestasi belajar IPA terbukti.

Hasil peneliti ini menguatkan pandangan Fryer (2001) bahwa penggunaan TIK dalam pembelajaran bertujuan untuk melatih keterampilan menggunakan TIK dengan cara mengintegrasikannya ke dalam aktifitas pembelajaran, bukan mengajarkan TIK tersebut sebagai mata pelajaran yang terpisah. Jadi, sudah saatnya TIK diintegrasikan ke dalam proses pembelajaran dan bukan hanya sekedar menjadi mata pelajaran yang terpisah. UNESCO (2002) menyatakan bahwa pengintegrasian TIK ke dalam proses pembelajaran memiliki tiga tujuan utama: 1) Untuk membangun "knowledge-based society habits" seperti kemampuan memecahkan masalah (problem solving), kemampuan berkomunikasi, kemampuan mencari, mengolah/mengelola informasi, mengubahnya menjadi pengetahuan baru dan mengkomunikasikannya kepada orang lain; 2) Untuk mengembangkan keterampilan menggunakan TIK (ICT literacy); dan 3) Untuk meningkatkan efektifitas dan efisiensi proses pembelajaran.

Hasil penelitian ini mendukung penelitian yang dilakukan Wijaya (2012) penerapan model pembelajaran yang lebih baik dapat meningkatkan pemahaman peserta didik atas konsep-konsep materi pelajaran, sehingga pada saat diadakan evaluasi belajar diperoleh hasil belajar yang meningkat. Media 
pembelajaran yang baik mencakup aspek visual, auditif dan motorik akan memudahkan peserta didik dalam belajar dan menanamkan konsep. Semakin banyak indera peserta didik yang terlibat dalam proses belajar maka semakin mudah anak belajar dan semakin bermakna. Hasil penelitian ini juga diperkuat dari hasil penelitian Juwita (2012), latar belakang dari penelitian ini adalah peserta didik memandang pelajaran matematika sebagai mata pelajaran yang paling sulit dan membosankan, sehingga peserta didik tidak memiliki minat untuk mempelajarinya dan hasil belajarpun menjadi rendah. Selain itu, rendahnya minat dan hasil belajar peserta didik diakibatkan karena selama ini pembelajaran yang dilakukan guru cenderung masih bersifat konvensional. Untuk mengentaskan permasalahan tersebut maka diterapkan penggunaan media Microsoft PowerPoint dalam pembelajaran sebagai upaya meningkatkan minat dan hasil belajar matematika peserta didik. Hasil dari penelitian tersebut menunjukkan adanya hubungan dan pengaruh antara penggunaan Microsoft PowerPoint dengan minat dan hasil belajar. Keterkaitan tersebut didukung oleh pendapat Sudjana (2011) bahwa nilai praktis media pembelajaran adalah media dapat memperbesar minat dan perhatian peserta didik untuk belajar serta media dapat meletakkan dasar untuk perkembangan belajar sehingga hasil belajar bertambah mantap.

Berdasarkan hasil penelitian ini penggunaan media berbasis IT berpengaruh lebih baik daripada peserta didik yang belajar dengan media pembelajaran sederhana (konvensional). Peserta didik yang diajarkan dengan memanfaatkan media IT dapat menghasilkan lebih banyak jawaban kreatif terhadap pertanyaan yang diberikan guru.

Ada perbedaan pengaruh kemandirian belajar yang tinggi dan kemandrian belajar yang rendah terhadap prestasi belajar IPA peserta didik Kelas V SD Negeri di Gugus Diponegoro Kecamatan Bae Kudus.

Hasil pengujian dengan uji ANAVA diperoleh bahwa terdapat perbedaan hasil belajar peserta didik dengan tingkat kemandirian belajar tinggi dengan peserta didik dengan tingkat kemandirian belajar rendah. Hal tersebut dapat dilihat dari hasil pengujian dengan ANAVA yang menunjukkan nilia signifikansi sebesar 0,009 $<0,05$ dengan demikian hipotesi yang menyatakan ada perbedaan pengaruh kemandirian belajar yang tinggi dan kemandrian belajar yang rendah terhadap prestasi belajar IPA peserta didik Kelas V SD Negeri di Gugus Diponegoro Kecamatan Bae Kudus, terbukti.

Hasil penelitian ini diperkuat dengan hasil penelitian Ronaldi (2013), hasil penelitian menunjukkan bahwa kemandirian belajar berpengaruh positif dan signifikan terhadap hasil belajar dengan tingkat pengaruhnya sebesar $(43,4 \%)$. Hasil penelitian sesuai dengan pendapat Sumarmo (2006) dengan kemandirian, peserta didik cenderung belajar lebih baik, mampu memantau, mengevaluasi, dan mengatur belajarnya secara efektif, menghemat waktu secara efisien, akan mampu mengarahkan dan mengendalikan diri sendiri dalam berfikir dan bertindak, serta tidak merasa bergantung pada orang lain secara emosional. Peserta didik yang mempunyai kemandirian belajar mampu menganalisis permasalahan yang kompleks, mampu bekerja secara individual maupun bekerja sama dengan kelompok, dan berani mengemukakan gagasan. Menurut Hiemstra (1994) bahwa kemandirian adalah perilaku peserta didik dalam mewujudkan kehendak atau keinginannya secara nyata dengan tidak bergantung pada orang lain, dalam hal ini adalah peserta didik tersebut mampu melakukan belajar sendiri, dapat menentukan cara belajar yang efektif, mampu melaksanakan tugas-tugas belajar dengan baik dan mampu untuk melakukan aktivitas belajar secara mandiri.

\section{Interaksi pengaruh antara media pembelajaran dan kemandirian belajar terhadap prestasi belajar IPA peserta didik Kelas V SD Negeri di Gugus Diponegoro Kecamatan Bae Kudus}

Hasil pengujian pengaruh bersama (interaksi) ditemukan bahwa penggunaan media pembelajaran dan kemandirian belajar peserta didik secara bersama-sama mempengaruhi hasil belajar. Hal tersebut dapat dilihat dari hasil uji ANAVA menunjukkan nilai signifikansi $p=0,024 \quad(p<0,05)$, dengan demikian hipotesis yang menyatakan ada interaksi pengaruh antara media pembelajaran dan kemandirian belajar terhadap prestasi belajar IPA peserta didik Kelas V SD Negeri di Gugus Diponegoro Kecamatan Bae 
Kudus, terbukti. Adapun interaksi yang muncul sebagai berikut; a) Prestasi belajar IPA dengan menggunakan media pembelajaran berbasis IT antara peserta didik yang memiliki kemandirian belajar tinggi dan rendah. Peserta didik yang memiliki kemandirian belajar tinggi memperoleh nilai rata-rata hasil belajar IPA 82,50 sedangkan peserta didik yang memiliki kemandirian belajar rendah memperoleh nilai rata-rata hasil belajar IPA sebesar 82,13 . Hal tersebut menunjukkan bahwa peserta didik yang diajarkan melalui media pembelajaran IT dengan kemandirian belajar rendah lebih baik dibandingkan dengan peserta didik yang memiliki kemandirian belajar tinggi. b) Prestasi belajar IPA dengan pembelajaran konvensional antara peserta didik yang memiliki kemandirian tinggi dan rendah. Peserta didik yang memiliki kemandirian belajar tinggi memperoleh nilai rata-rata hasil belajar IPA 79.42 sedangkan peserta didik yang memiliki kemandirian belajar rendah memperoleh nilai rata-rata hasil belajar IPA sebesar 78.22. c) Prestasi belajar IPA dengan menggunakan media pembelajaran berbasis IT dan memiliki kemandirian belajar rendah dengan pembelajaran konvensional dan memiliki kemandirian belajar rendah.

Peserta didik yang yang diajarkan menggunakan media IT dengan kemandirian belajar rendah memperoleh nilai rata-rata 82,50 sedangkan peserta didik yang diajarkan secara konvensional dengan kemandirian rendah memperoleh nilai rata-rata 78,22. d) Prestasi belajar IPA dengan menggunakan media pembelajaran IT dan memiliki kemandirian belajar tinggi dengan pembelajaran konvensional dan memiliki kemandirian belajar tinggi. Peserta didik yang diajarkan menggunakan media IT dan memiliki tingkat kemandirian belajar tinggi memperoleh nilai rata-rata 82,13 sedangkan peserta didik yang diajarkan secara konvensional dengan kemandirian belajar tinggi memperoleh nilai rata-rata 79,42. e) Prestasi belajar IPA dengan menggunakan media pembelajaran IT dan memiliki kemandirian belajar rendah dengan pembelajaran konvensional dan memiliki kemandirian belajar tinggi. Peserta didik yang diajarkan menggunakan media IT dengan kemandirian belajar rendah memperoleh nilai rata-rata 82,50 sedangkan peserta didik yang diajarkan secara konvensional dengan kemandirian belajar tinggi memperoleh nilai rata-rata 79,42. f) Prestasi belajar IPA dengan menggunakan media pembelajaran IT dan memiliki kemandirian belajar tinggi dengan pembelajaran secara konvensional dan memiliki kemandirian belajar rendah. Peserta didik didik yang diajarkan menggunakan media IT dengan kemandirian belajar tinggi memperoleh nilai rata-rata 82,13 , sedangkan peserta didik yang diajarkan secara konvensional dengan kemandirian belajar rendah memperoleh nilai rata-rata 78,22.

Kesimpulan bahwa penggunaan media pembelajaran berbasis IT didukung dengan kemandirian belajar peserta didik yang tinggi akan mampu meningkatkan prestasi belajar peserta didik.

\section{SIMPULAN}

Berdasarkan hasil analisis data dan pembahasan hasil penelitian, dapat disimpulkan sebagai berikut 1) Hasil belajar peserta didik pada mata pelajaran IPA dengan menggunakan media berbasis IT lebih baik dibandingkan dengan hasil belajar peserta didik yang diajarkan secara konvensional. 2) Hasil belajar peserta didik yang memiliki tingkat kemandirian belajar tinggi lebih baik dibandingkan dengan peserta didik yang memiliki kemandirian belajar rendah. 3) Terdapat interaksi antara media pembelajaran yang digunakan dengan tingkat kemandirian belajar terhadap hasil belajar. a) Peserta didik yang diajarkan melalui media pembelajaran IT dengan kemandirian belajar rendah lebih baik dibandingkan dengan peserta didik yang memiliki kemandirian belajar tinggi. b) Peserta didik yang memiliki kemandirian belajar kategori tinggi hasilnya lebih baik dibandingkan peserta didik yang memiliki kemandirian belajar rendah. c) Peserta didik yang diajarkan menggunakan media IT dengan kemandirian belajar rendah, lebih baik dibandingkan dengan peserta didik yang diajarkan secara konvensional dengan kemandirian belajar rendah. d) Peserta didik yang diajarkan menggunakan media pembelajaran IT dengan kemandirian belajar tinggi hasilnya lebih baik dibandingkan peserta didik yang diajarkan secara konvensional dengan kemandirian belajar tinggi. e) Peserta didik yang diajarkan menggunakan media IT dengan kemandirian belajar rendah hasilnya lebih baik dibandingkan dengan peserta didik yang diajarkan secara konvensional 
dengan kemandirian belajar tinggi. f) Peserta didik yang diajarkan dengan media pembelajaran IT dengan kemandirian belajar tinggi hasilnya lebih baik dibandingkan dengan peserta didik yang diajarkan secara konvensional dengan kemandirian rendah.

\section{IMPLIKASI}

Implikasi Teoritis. Dapat memberikan sumbangan keilmuan tentang pentingnya pemanfaatan media pembelajaran untuk meningkatkan hasil belajar peserta didik. Implikasi Praktis. Sebagai masukan pada peserta didik tentang pentingnya kemandirian belajar untuk meningkatkan hasil belajar peserta didik dan Sebagai masukan bagi guru untuk menerapkan media pembelajaran dalam pengelolaan pembelajaran terhadap peserta didik.

\section{SARAN}

Peserta didik untuk lebih giat lagi dalam belajar dengan menumbuhkan semangat kemandirian belajarnya. Guru dalam menyampaikan materi pembelajaran sebaiknya dengan media pembelajaran berbasis IT untuk meningkatkan prestasi belajar peserta didik. Peneliti lain diharapkan menindak lanjuti penelitian ini untuk dikembangkan lebih luas ruang lingkupnya.

\section{DAFTAR PUSTAKA}

Achmad, I. F. (2008). Pengaruh Kemandirian Belajar dan Disiplin Belajar terhadap Prestasi Belajar Siklus Akuntansi Siswa Kelas X SMK Negeri 7 Yogyakarta Tahun Ajaran 2007/2008. Tesis. Fakultas Ekonomi Universitas Negeri Yogyakarta.

Budiarini, D.P. (2011). Penerapan Layanan Informasi Belajar Untuk Meningkatkan Kemandirian Belajar Siswa Kelas VII SMPN 1 Sukasada. Jurnal Penelitian Bimbingan dan Konseling Universitas Pendidikan Ganesha Singaraja (Oniline).

Fryer, W. A. (2001). Strategy for effective Elementary Technology Integration. (Online) Tersedia dalam http://www.wtvi.com/teks/ integrate/tcea2001/powerpointoutline.pdf Diunduh Tanggal 12 Mei 2015.

Hiemstra. (1994). Self-Directed Learning. In T. Husen \& T. N. Postlewaite (Eds). The International Encyclopedia of Education (second edition) Oxford: Porgomon Press. http: //home.twcny.rr.com/hiemstra/sdlhdbk.html/ diakses pada tanggal 21 April 2015.

Juwita, G. R. (2012). Pengaruh Penggunaan Mcrosoft Power Point Terhadap Minat dan Hasil Belajar Matematika Peserta didik Didik Pada Materi Segitiga dan Segi Empat. Jurnal Penelitian Jurusan Tadris Matematika (Online).

Ronaldi. (2013). Pengaruh Dukungan Orang Tua dan Kemandirian Belajar Terhadap Hasil Belajar Ekonomi Siswa Kelas XI IPS SMAN 6 Padang. Skripsi (Tidak Diterbitkan). Padang: Fakultas Ekonomi Universitas Negeri Padang.

Sudjana. (2011). Metoda Statistika. Bandung: Tarsito

Sugiyono. (2011). Metode Penelitian Pendidikan Kuantitatif Kualitatif dan R\&D. Bandung: Alfabeta.

Syam, M. N. (1999). Metodologi Penelitian Dakwah. Solo: CV. Ramadhan.

UNESCO Institute for Information Technologies in Education. (2002). Toward Policies for Integrating ICTS into Education. High-Level Seminar for Decision Makers and Policy-Makers, Moscow 2002. 
Wijaya, M. (2012). Pengembangan Model Pembelajaran e-Learning Berbasis Web dengan Prinsip ePedagogy dalam Meningkatkan Hasil Belajar. Skripsi (Tidak diterbitkan). Uuniversitas Pendidikan Indonesia.

Yuliatmojo, P. (2006). Mempersiapkan Guru Pada Strategi Pembelajaran Berbasis Teknologi Informasi Dan Komunikasi. Proseding Seminar Internasional Peran LPTK Dalam Pengembangan Pendidikan Vokasi di Indonesia 